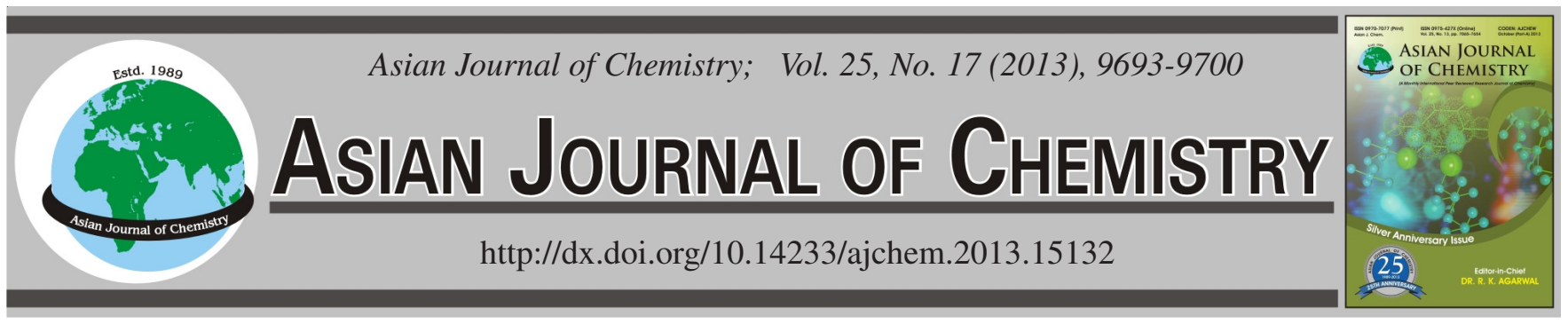

\title{
Kinetic Study of Anodic Corrosion of Copper in Phosphoric Acid and Effects of Some Phenols Derivatives
}

\author{
S.M. AbDel-HaleEM ${ }^{1}$, A.M. Ahmed ${ }^{2, *}$ and M.I. ShadAD ${ }^{1}$
}

${ }^{1}$ Department of Chemistry, Faculty of Science, Zagazig University, Zagazig, Egypt

${ }^{2}$ Department of Chemistry, Faculty of Science, Alexandria University, Ibrahimia and P.O. Box 426, Alexandria 21321, Egypt

*Corresponding author: E-mail: profabdelmonem@gmail.com

\begin{abstract}
Electropolishing of copper in phosphoric acid is considered as corrosion rate of copper and due to the economic importance of copper there are several researches deals with acceleration and inhibition of this process. From the previous studies, this process may be controlled by the presence of some materials which may cause acceleration or inhibition of this process. In this paper the electropolishing process inhibited with different ratio by addition of some organic phenols derivatives by addition with concentration $\left(10^{-5}-10^{-2} \mathrm{~mol} \mathrm{~L}^{-1}\right)$. The results reveal that organic phenols have strongest inhibitive effect ranging from 4.92 to $40.98 \%$ and the thermodynamic parameters and as well as adsorption isotherm were given.
\end{abstract}

Key Words: Electropolishing of copper, Phenols, Current, Inhibition of corrosion.

\section{INTRODUCTION}

Due to its excellent thermal conductivity and good mechanical workability, copper is a material commonly used in heating and cooling systems. Scale and corrosion products have a negative effect on heat transfer and they cause a decrease in the heating efficiency of the equipments. Therefore, periodic descaling and cleaning in hydrochloric acid pickling solution are necessary.

Many corrosion inhibitors can be used to eliminate the undesirable destructive effect and prevent metal dissolution. Copper normally does not displace hydrogen from acid solutions and therefore is virtually unattached in non-oxidizing conditions. In fact, the uprising hydrogen bubbles induce a radial momentum transfer which enhances the rate of copper corrosion ${ }^{1}$. Copper dissolution in acidic medium has been studied by several researchers ${ }^{2,3}$.

Corrosion inhibitors can be used to prevent copper dissolution. Amines are known to be very effective inhibitors for metal and alloys in different corrosion media. Benzotriazole, for instances, was studied and found to have excellent inhibition properties in several corrosion environments ${ }^{4,5}$. The molecule contains nitrogen atoms and it is also useful in preventing copper staining and tarnishing ${ }^{6}$.

One of the most important methods in the protection of copper against corrosion is the use of organic inhibitors ${ }^{7}$.
Organic compounds containing polar groups including nitrogen, sulfur, oxygen and heterocyclic compounds with polar functional groups and conjugated double bonds have been reported to inhibit copper corrosion ${ }^{8-13}$.

The inhibiting action of these organic compounds is usually attributed to their interactions with the copper surface via their adsorption. Polar functional groups are regarded as the reaction center that stabilizes the adsorption process, in general, the adsorption of an inhibitor on a metal surface depends on the nature and the surface charge of the metal, the adsorption mode, its chemical structure and the type of electrolyte solution ${ }^{14}$.

The phenomenon of electropolishing is first discovered by Jaquet ${ }^{15}$. A lot of work has been done on this phenomenon owing to its important as metal finishing process. A great deal of work has been directed to study the mechanism of electro polishing as well as to establish conditions for different metals and alloys involved in the process.

Mechanistic studies have revealed that electro polishing is diffusion controlled process taking place at the limiting current which is attained most probably when the diffusion layer becomes saturated with $\mathrm{Cu}$ in, electropolishing of copper.

Therefore, the values of the limiting current which determined the polishing rate depends on the rate of mass transfer of $\mathrm{Cu}^{2+}$ from the diffusion layer to the bulk solution. The latter depends on the relative movement of the ions at the anode and 
in the electrolyte. Earlier works studied the factors affecting the limiting current have overlooked the effect of anode geometry as an important factor in determining the value of the limiting current.

The work of Hackerman and Hard ${ }^{16}$ indicated that, electro polishing of copper in phosphoric acid results in the formation of a thin film of a phosphorous compound. The nature of solid film is not known. The radio tracer work suggested that, it a phosphorous containing compound. Other work based on electron diffraction showed .That, the film is an oxide. Hull cell studies by Lurking suggested that, copper oxides are formed during electro polishing of copper in $\mathrm{H}_{3} \mathrm{PO}_{4}$.

It can be defined that, a viscous layer is present at the surface of copper anodes during electro polishing as shown by the work of Walton ${ }^{17}$. It is likely that, the viscous layer controls the rate of dissolution of the solid film and that electro polishing occurs in those electrolytes in which there is a relationship, between the rate of electro polishing and the formation of the solid film and also between the rate of dissolution and diffusion of the solid product through the viscous layer. The objective of this study is to investigate the effect of some organic phenols (phenol, $p$-amino phenol, $o$-amino phenol, $o$-cresol, $p$-cresol and $m$-cresol) on the inhibition of copper corrosion in phosphoric acid at different conditions. The rate of copper corrosion is determined by measuring the anodic limiting current.

\section{EXPERIMENTAL}

Analar grade $\mathrm{H}_{3} \mathrm{PO}_{4}(98 \%$ w/w) and double distilled water used to prepare the electrolyte. Phenols derivatives were used in this work are Phenol, $p$-amino phenol, $o$-amino phenol, $o$ cresol, $p$-cresol and $m$-cresol.<smiles>Oc1ccccc1</smiles>

Phenol<smiles>Cc1ccccc1O</smiles>

$o$-cresol<smiles>Nc1ccc(O)cc1</smiles><smiles></smiles>

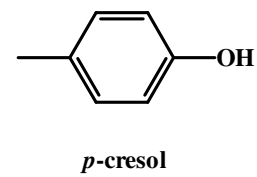

-cresol $o$-amino phenol<smiles>Nc1ccccc1O</smiles>

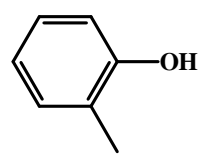

$m$-cresol
Measurements of the limiting current: Polarization curves were obtained by increasing the cell current step wise and the steady state anode potential against a reference electrode consisted of a wire immersed in a cup of Luggin tube filled with phosphoric acid concentration similar to that in the cell, the tip of the Luggin tube was placed 0.5 -from the anode. The potential difference between the anode and the reference was measured by high impedance potentiometer. Five phosphoric acid concentrations $(6,8,10,12$ and $14 \mathrm{M})$ were prepared from Analar grade phosphoric acid distilled water. The anode height varied from $1-5 \mathrm{~cm}$. Before each run, the back part of the anode was insulated with polystyrene lacquers and the active surface of the anode was polished with fine emery paper, degreased with trichloroethylene, washed with alcohol and finally rinsed in distilled water. Electrode treatment was similar to that used by Wilke et al. ${ }^{18}$. Organic acid concentration were $10^{-5}-10^{-2} \mathrm{~mol} \mathrm{~L}^{-1}$. The rate of electro polishing of copper was determined at $25^{\circ} \mathrm{C}$ (Fig. 1).

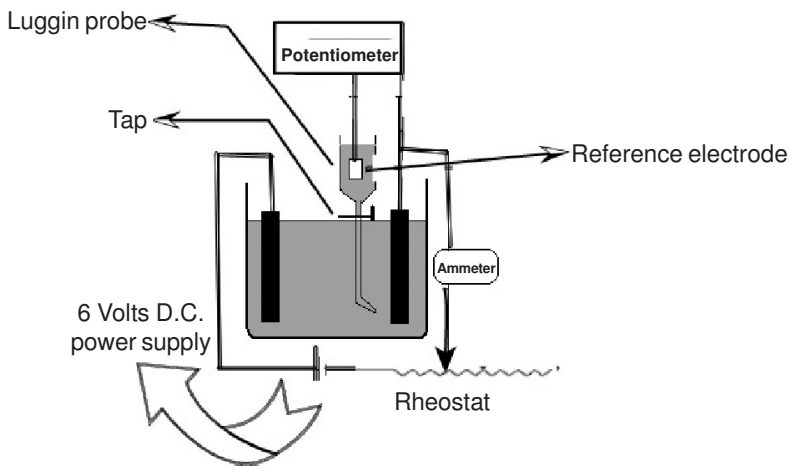

Fig. 1. Electrolytic cell and the electrical circuit

Rotating cylinder electrode (RCE) cell and circuit: Fig. 2 is a block diagram of the apparatus which permits the rotating of a cylinder electrode at accurately controlled angular velocities. The shaft was driven by a variable speed motor. The frequency of rotation, recorded as revolution per minute was counted by an optical tachometer. The glass vessel which holds electrolyte is $13 \mathrm{~cm}$ diameter. The electrical circuit consists of 6 volts D.C. power supply, a multirange ammeter connected in series with the cell to measure the current and voltmeter is connected in parallel with the cell to measure its voltage.

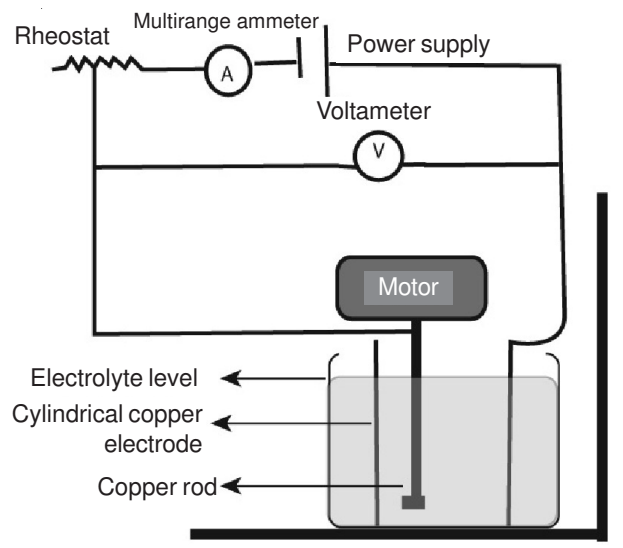

Fig. 2. Electrolytic cell and electrical circuit

The anode consists of a copper metal cylinder $2 \mathrm{~cm}$ diameter and $7 \mathrm{~cm}$ length. The sides and back of the cylinder as well as the drive shaft are insulated by epoxy-resin. The cathode is made of a cylinder copper metal electrode of $12 \mathrm{~cm}$ diameter; it's also acted as the reference electrode by virtue of its high surface area compared to that of the anode.

\section{RESULTS AND DISCUSSION}

Leveling process: Fig. 3 shows a typical polarization curves obtained using different concentration of $p$-cresol as 

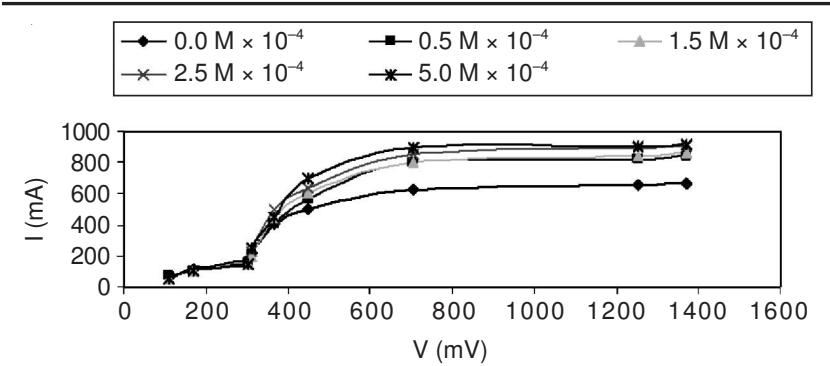

Fig. 3. Relation between $\mathrm{I}(\mathrm{mA})$ and $\mathrm{V}(\mathrm{mV})$ in presence of $p$-cresol at 25 ${ }^{\circ} \mathrm{C}$ and $8 \mathrm{M} \mathrm{H}_{3} \mathrm{PO}_{4}$ for divided cell at $2 \mathrm{~cm}$ height

divided cell at $25^{\circ} \mathrm{C}$ and $8 \mathrm{M} \mathrm{H}_{3} \mathrm{PO}_{4}$. The limiting current at which polishing take place was determined from those polarization curves and used to calculate the mass transfer coefficient (K) of copper polishing in $\mathrm{H}_{3} \mathrm{PO}_{4}$ from the equation:

$$
\mathrm{K}=\frac{\mathrm{I}}{\mathrm{zFC}_{0}}
$$

$\mathrm{C}_{0}$ : bulk concentration, z: valence and F: Faraday number. Table-1 gives the values of limiting current at all temperatures for all compounds.

Leveling is the principle process in electropolishing ${ }^{19}$. Mayer et al..$^{20}$ explained the necessity to separate between anode and cathode by non-conductive slit to prevent the gas bubbles transfer to the anode surface and enhance the homogenous distribution of electric current. The study of leveling based on the classical current voltage curves of electropolishing as shown in Fig. 3. A typical polarogram obtained in this study for phenols derivatives in case of divided and undivided cell.

The curve divided into two parts: in the first part, the current density (c.d.) is proportional to the voltage. At the second part of the curve, the metal undergoes electropolishing.
Effect of electrode height on limiting current: Fig. 4 shows that the limiting current density decreases with the increase in height. In electro-polishing and generally for anodic dissolution of metal, the direction of flow of the thermodynamic boundary layer and the diffusion layer increase in the downward direction, i.e., the resistance to mass transfer increases in the downward direction. Accordingly, the local limiting current density increases in the up-ward direction of the anode. This explains why polishing is attained at the upper parts of the electrode before the lower parts at the limiting current region. This was confirming by visual observation during electropolishing. The average limiting current density decreases with increase in the height according to the equation $^{21}$ :

$$
\mathrm{I}_{1}=\frac{\mathrm{C}}{\mathrm{H}^{\mathrm{a}}}
$$

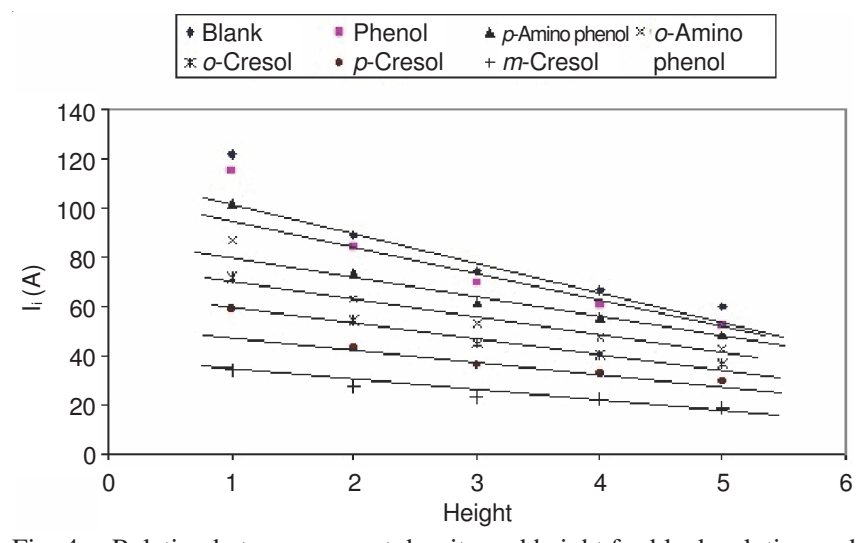

Fig. 4. Relation between current density and height for blank solution and in presence of all compounds

TABLE-1

\begin{tabular}{|c|c|c|c|c|c|c|c|c|}
\hline \multirow{2}{*}{ Conc. $\mathrm{M} \times 10^{6}$} & \multicolumn{4}{|c|}{ Phenol } & \multicolumn{4}{|c|}{$o$-Cresol } \\
\hline & $25^{\circ} \mathrm{C}$ & $30^{\circ} \mathrm{C}$ & $35^{\circ} \mathrm{C}$ & $40^{\circ} \mathrm{C}$ & $25^{\circ} \mathrm{C}$ & $30^{\circ} \mathrm{C}$ & $35^{\circ} \mathrm{C}$ & $40{ }^{\circ} \mathrm{C}$ \\
\hline 0.0 & 710 & 750 & 800 & 860 & 710 & 750 & 800 & 860 \\
\hline 0.5 & 650 & 670 & 720 & 730 & 570 & 585 & 600 & 620 \\
\hline 1.0 & 580 & 600 & 630 & 640 & 540 & 540 & 555 & 570 \\
\hline 1.5 & 550 & 570 & 590 & 610 & 490 & 510 & 530 & 545 \\
\hline 2.0 & 510 & 530 & 540 & 550 & 460 & 480 & 500 & 520 \\
\hline 2.5 & 470 & 485 & 500 & 530 & 420 & 435 & 450 & 470 \\
\hline 3.0 & 430 & 445 & 460 & 500 & 390 & 405 & 420 & 430 \\
\hline \multirow[t]{2}{*}{5.0} & 405 & 420 & 435 & 450 & 275 & 290 & 310 & 330 \\
\hline & \multicolumn{4}{|c|}{$p$-Amino phenol } & \multicolumn{4}{|c|}{$p$-Cresol } \\
\hline 0.0 & 710 & 750 & 800 & 860 & 710 & 750 & 800 & 860 \\
\hline 0.5 & 620 & 640 & 660 & 680 & 550 & 570 & 585 & 600 \\
\hline 1.0 & 565 & 585 & 600 & 620 & 520 & 540 & 555 & 570 \\
\hline 1.5 & 530 & 545 & 560 & 580 & 490 & 500 & 510 & 520 \\
\hline 2.0 & 485 & 500 & 515 & 570 & 430 & 445 & 450 & 465 \\
\hline 2.5 & 460 & 470 & 480 & 490 & 410 & 425 & 440 & 450 \\
\hline 3.0 & 425 & 440 & 455 & 470 & 370 & 380 & 390 & 405 \\
\hline \multirow[t]{2}{*}{5.0} & 385 & 400 & 410 & 420 & 210 & 230 & 250 & 280 \\
\hline & \multicolumn{4}{|c|}{$o$-Amino phenol } & \multicolumn{4}{|c|}{$m$-Cresol } \\
\hline 0.0 & 710 & 750 & 800 & 850 & 710 & 750 & 800 & 860 \\
\hline 0.5 & 590 & 610 & 630 & 650 & 510 & 530 & 550 & 570 \\
\hline 1.0 & 550 & 470 & 580 & 600 & 480 & 495 & 510 & 530 \\
\hline 1.5 & 510 & 525 & 540 & 550 & 420 & 435 & 450 & 470 \\
\hline 2.0 & 470 & 480 & 490 & 500 & 370 & 385 & 400 & 420 \\
\hline 2.5 & 450 & 460 & 470 & 480 & 300 & 320 & 340 & 350 \\
\hline 3.0 & 400 & 410 & 420 & 440 & 240 & 260 & 280 & 300 \\
\hline 5.0 & 350 & 370 & 385 & 400 & 145 & 160 & 180 & 200 \\
\hline
\end{tabular}

VALUES OF LIMITING CURRENT AT DIFFERENT TEMPERATURES FOR ALL COMPOUNDS USED IN CASE OF DIVIDED CELL 
where $\mathrm{C}$ is constant, $\mathrm{H}$ is the height of electrode, $\mathrm{a}$ is constant depends on the type of solution, [a $=0.502$ for undivided cell].

Effect of organic compounds concentration the limiting current: Table- 1 gives the observed limiting current at all concentrations of phenol at all temperatures. The observed limiting current, which represent the rate of copper metal corrosion in phosphoric acid, are found that, the limiting current rate of electropolishing decrease with increasing the concentration of phenols derivatives additives (Table-1). It is recommended on the basis of results that, it may use in this range of concentration to inhibit the corrosion of copper metal in $8 \mathrm{M} \mathrm{H}_{3} \mathrm{PO}_{4}$ acid in all type of phenols derivatives to be used in this work $^{22}$. The mass transfer coefficient of polishing process, which used in data correlation, calculated from the limiting current using the eqn. 1.

The above equation based on the finding of previous studies $^{23}$. If the limiting current in absence of organic compounds (I) and in the presence of organic compounds $\left(\mathrm{I}_{1}\right)$, the percentage of inhibition can be calculated from the following equation:

$$
\text { Inhibition }(\%)=\frac{\mathrm{I}-\mathrm{I}_{1}}{\mathrm{I}} \times 100
$$

Table- 2 and Fig. 5 show that the per cent inhibition caused by organic compounds ranges from 4.92 to $40.98 \%$ depending on the organic phenols derivatives and their concentrations.

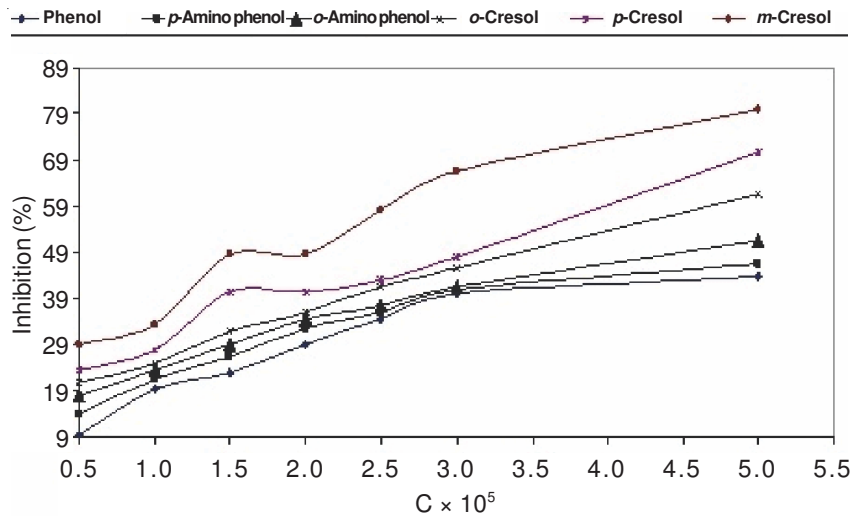

Fig. 5. Relation between $\%$ inhibition and concentration of all compounds at $25^{\circ} \mathrm{C}$

The limiting current decreases with increasing the concentration of organic compounds. This agrees with the finding of other authors who worked within the same range of concentration using other inhibitors ${ }^{24}$. The deceasing in the limiting current with increasing the concentration of organic phenols derivatives is attributing to: (a) The solubility of dissolved copper phosphate in phosphoric acid, which is responsible for the limiting current, decreases with increasing phosphoric acid concentration. (b) The viscosity of the solution increases with increasing phenols derivatives concentration with consequence decrease in the diffusivity of' $\mathrm{Cu}^{2+}$ according to Stokes-Einstein equation $^{25}$.

Adsorption isotherm: It generally assumed that the adsorption isotherm of the inhibitor at the metal solution interface is the first main role the mechanism of inhibitors action in aggressive acid media. Table- 3 shows the relation between limiting current and surface coverage in $8 \mathrm{M} \mathrm{H}_{3} \mathrm{PO}_{4}$ for all phenols used: (a) Electrostatic attraction between charged molecules and the charged metal. (b) Interaction of lone pairs of electron in the molecules with the metal. (c) Interaction of electron with metal. A combination of the above ${ }^{26}$.

Figs. 6-11 shows the Flory-Huggins adsorption isotherm for copper electrode in $\mathrm{H}_{3} \mathrm{PO}_{4}$ plotted as $\log \theta / \mathrm{C}$ against $\log$ (1- $\theta)$ at $25^{\circ} \mathrm{C}$. A straight line is obtained with a slope $\mathrm{x}$ and intercept $\log \mathrm{xK}$. The experimental data fits the Flory-Huggins adsorption isotherm which represented by:

$$
\log \frac{\theta}{C}=\log x K+x \log (1-\theta)
$$

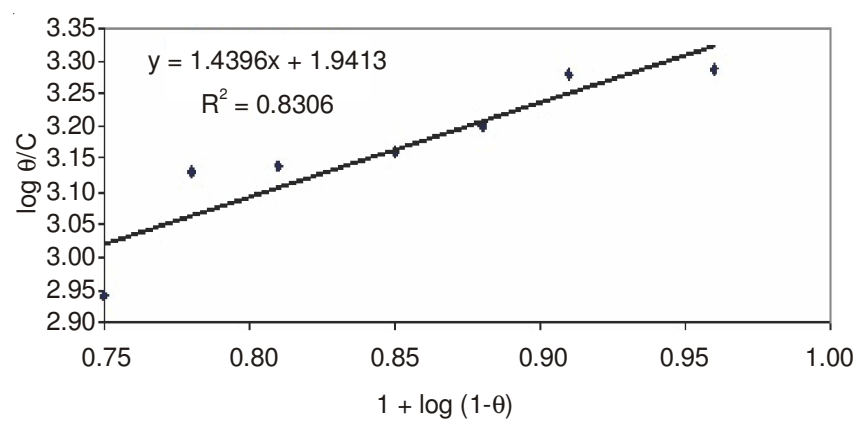

Fig. 6. Flory-Huggins adsorption isotherms at $25^{\circ} \mathrm{C}$ for phenol (I)

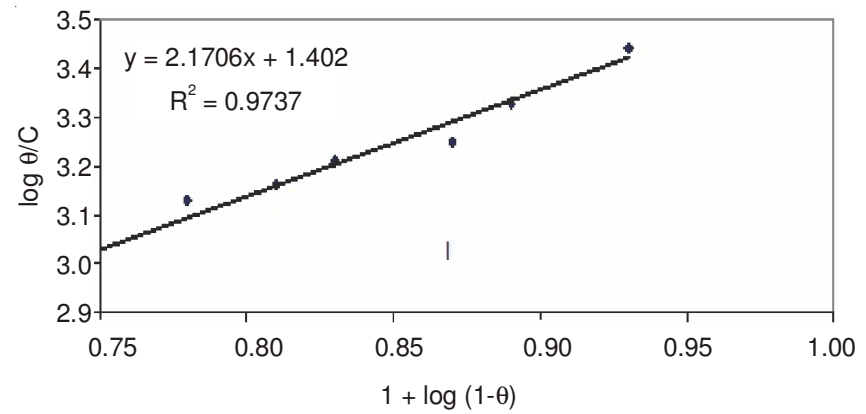

Fig. 7. Flory-Huggins adsorption isotherms at $25^{\circ} \mathrm{C}$ for $p$-amino (II)

TABLE-2

RELATION BETWEEN PERCENTAGE INHIBITION AND CONCENTRATION OF ALL COMPOUNDS AT $25^{\circ} \mathrm{C}$

\begin{tabular}{ccccccc}
\hline \multirow{2}{*}{$\mathrm{C} \times 10^{5}\left(\mathrm{~mol} \mathrm{~L}^{-1}\right)$} & \multicolumn{5}{c}{ Inhibition (\%) } \\
\cline { 2 - 7 } & Phenol (I) & $p$-Amino phenol (II) & $o$-Amino phenol (III) & $o$-Cresol(IV) & $p$-Cresol(V) & $m$-Cresol(VI) \\
\hline 0.5 & 9.7 & 13.9 & 18.1 & 20.8 & 23.6 & 29.2 \\
1.0 & 19.4 & 21.5 & 23.6 & 25.0 & 27.8 & 33.3 \\
1.5 & 23.1 & 26.4 & 29.2 & 31.9 & 40.3 & 48.6 \\
2.0 & 29.2 & 32.6 & 34.7 & 36.1 & 40.3 & 48.6 \\
2.5 & 34.7 & 36.1 & 37.5 & 41.7 & 43.1 & 58.3 \\
3.0 & 40.2 & 40.9 & 41.7 & 45.8 & 48 & 66.7 \\
5.0 & 43.8 & 46.5 & 51.4 & 61.8 & 70.8 & 80.1 \\
\hline
\end{tabular}




\begin{tabular}{|c|c|c|c|c|c|c|c|c|}
\hline \multicolumn{9}{|c|}{$\begin{array}{c}\text { TABLE-3 } \\
\text { LIMITING CURRENT AND SURFACE COVERAGE IN } 8 \text { M PHOSPHORIC ACID WITH } \\
\text { DIFFERENT PHENOLS DERIVATIVES CONCENTRATIONS FOR DIVIDED CELL }\end{array}$} \\
\hline Conc. $\mathrm{M} \times 10^{4}$ & Inh. (\%) & $\log C$ & $\theta$ & $\theta / 1-\theta$ & $\log (\theta / 1-\theta)$ & $1-\theta$ & $\log (1-\theta)$ & $\log \theta / \mathrm{C}$ \\
\hline \multicolumn{9}{|c|}{ Phenol (I) } \\
\hline 0.5 & 9.72 & -4.30 & 0.097 & 0.108 & -0.97 & 0.92 & -0.04 & 3.29 \\
\hline 1.0 & 19.44 & -4.00 & 0.194 & 0.241 & -0.62 & 0.81 & -0.09 & 3.28 \\
\hline 1.5 & 23.61 & -3.82 & 0.236 & 0.309 & -0.51 & 0.76 & -0.12 & 3.20 \\
\hline 2.0 & 29.17 & -3.70 & 0.292 & 0.412 & -0.39 & 0.71 & -0.15 & 3.16 \\
\hline 2.5 & 34.72 & -3.60 & 0.347 & 0.532 & -0.27 & 0.65 & -0.19 & 3.14 \\
\hline 3.0 & 40.28 & -3.52 & 0.402 & 0.674 & -0.17 & 0.60 & -0.22 & 3.13 \\
\hline 5.0 & 43.75 & -3.30 & 0.438 & 0.778 & -0.11 & 0.56 & -0.25 & 2.94 \\
\hline \multicolumn{9}{|c|}{ p-Amino phenol (II) } \\
\hline 0.5 & 13.89 & -4.30 & 0.139 & 0.161 & -0.79 & 0.85 & -0.07 & 3.44 \\
\hline 1.0 & 21.53 & -4.00 & 0.215 & 0.274 & -0.56 & 0.78 & -0.11 & 3.33 \\
\hline 1.5 & 26.39 & -3.80 & 0.264 & 0.358 & -0.45 & 0.74 & -0.13 & 3.25 \\
\hline 2.0 & 32.64 & -3.70 & 0.326 & 0.485 & -0.315 & 0.68 & -0.17 & 3.21 \\
\hline 2.5 & 36.11 & -3.60 & 0.361 & 0.565 & -0.25 & 0.65 & -0.19 & 3.16 \\
\hline 3.0 & 40.97 & -3.52 & 0.409 & 0.694 & -0.16 & 0.60 & -0.22 & 3.13 \\
\hline 5.0 & 46.53 & -3.30 & 0.465 & 0.870 & -0.06 & 0.54 & -0.27 & 2.97 \\
\hline \multicolumn{9}{|c|}{$o$-Amino phenol (III) } \\
\hline 0.5 & 9.72 & -4.30 & 0.097 & 0.108 & -0.97 & 0.92 & -0.04 & 3.29 \\
\hline 1.0 & 19.44 & -4.00 & 0.194 & 0.241 & -0.62 & 0.81 & -0.09 & 3.28 \\
\hline 1.5 & 23.61 & -3.82 & 0.236 & 0.309 & -0.51 & 0.76 & -0.12 & 3.20 \\
\hline 2.0 & 29.17 & -3.70 & 0.292 & 0.412 & -0.39 & 0.71 & -0.15 & 3.16 \\
\hline 2.5 & 34.72 & -3.60 & 0.347 & 0.532 & -0.27 & 0.65 & -0.19 & 3.14 \\
\hline 3.0 & 40.28 & -3.52 & 0.402 & 0.674 & -0.17 & 0.60 & -0.22 & 3.13 \\
\hline 5.0 & 43.75 & -3.30 & 0.438 & 0.778 & -0.11 & 0.56 & -0.25 & 2.94 \\
\hline \multicolumn{9}{|c|}{$o$-Cresol(IV) } \\
\hline 0.5 & 13.89 & -4.30 & 0.139 & 0.161 & -0.79 & 0.85 & -0.07 & 3.44 \\
\hline 1.0 & 21.53 & -4.00 & 0.215 & 0.274 & -0.56 & 0.78 & -0.11 & 3.33 \\
\hline 1.5 & 26.39 & -3.80 & 0.264 & 0.358 & -0.45 & 0.74 & -0.13 & 3.25 \\
\hline 2.0 & 32.64 & -3.70 & 0.326 & 0.485 & -0.315 & 0.68 & -0.17 & 3.21 \\
\hline 2.5 & 36.11 & -3.60 & 0.361 & 0.565 & -0.25 & 0.65 & -0.19 & 3.16 \\
\hline 3.0 & 40.97 & -3.52 & 0.409 & 0.694 & -0.16 & 0.60 & -0.22 & 3.13 \\
\hline 5.0 & 46.53 & -3.30 & 0.465 & 0.870 & -0.06 & 0.54 & -0.27 & 2.97 \\
\hline \multicolumn{9}{|c|}{$p$-Cresol (V) } \\
\hline 0.5 & 9.72 & -4.30 & 0.097 & 0.108 & -0.97 & 0.92 & -0.04 & 3.29 \\
\hline 1.0 & 19.44 & -4.00 & 0.194 & 0.241 & -0.62 & 0.81 & -0.09 & 3.28 \\
\hline 1.5 & 23.61 & -3.82 & 0.236 & 0.309 & -0.51 & 0.76 & -0.12 & 3.20 \\
\hline 2.0 & 29.17 & -3.70 & 0.292 & 0.412 & -0.39 & 0.71 & -0.15 & 3.16 \\
\hline 2.5 & 34.72 & -3.60 & 0.347 & 0.532 & -0.27 & 0.65 & -0.19 & 3.14 \\
\hline 3.0 & 40.28 & -3.52 & 0.402 & 0.674 & -0.17 & 0.60 & -0.22 & 3.13 \\
\hline 5.0 & 43.75 & -3.30 & 0.438 & 0.778 & -0.11 & 0.56 & -0.25 & 2.94 \\
\hline \multicolumn{9}{|c|}{$m$-Cresol (VI) } \\
\hline 0.5 & 13.89 & $\begin{array}{l}-4.30 \\
\end{array}$ & 0.139 & 0.161 & -0.79 & 0.85 & -0.07 & 3.44 \\
\hline 1.0 & 21.53 & -4.00 & 0.215 & 0.274 & -0.56 & 0.78 & -0.11 & 3.33 \\
\hline 1.5 & 26.39 & -3.80 & 0.264 & 0.358 & -0.45 & 0.74 & -0.13 & 3.25 \\
\hline 2.0 & 32.64 & -3.70 & 0.326 & 0.485 & -0.315 & 0.68 & -0.17 & 3.21 \\
\hline 2.5 & 36.11 & -3.60 & 0.361 & 0.565 & -0.25 & 0.65 & -0.19 & 3.16 \\
\hline 3.0 & 40.97 & -3.52 & 0.409 & 0.694 & -0.16 & 0.60 & -0.22 & 3.13 \\
\hline 5.0 & 46.53 & -3.30 & 0.465 & 0.870 & -0.06 & 0.54 & -0.27 & 2.97 \\
\hline
\end{tabular}

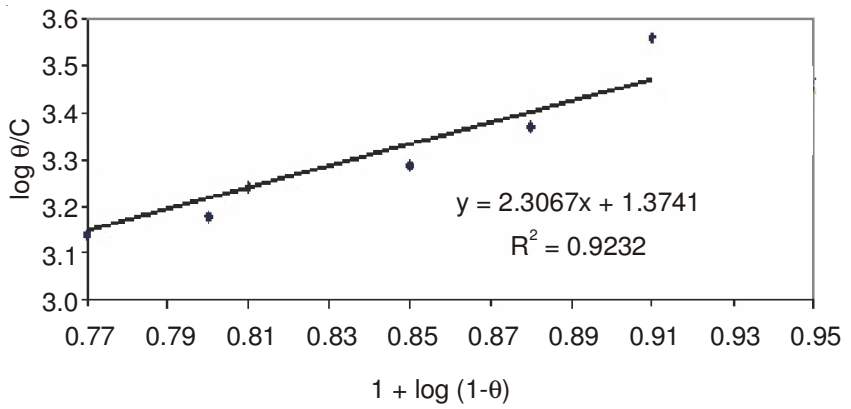

Fig. 8. Flory-Huggins adsorption isotherms at $25^{\circ} \mathrm{C}$ for $o$-amino phenol (III)

where $\mathrm{x}$ is the number of water molecules replaced by one molecule of the inhibitor. It is clear that, the surface coverage

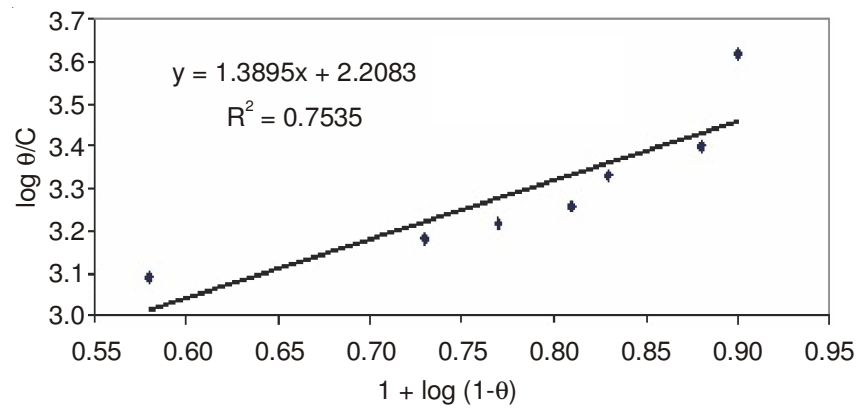

Fig. 9. Flory-Huggins adsorption isotherms at $25^{\circ} \mathrm{C}$ for $o$-cresol (IV)

data are useful for discussing adsorption characteristics. The adsorption of inhibitors at metal solution interface may be due 


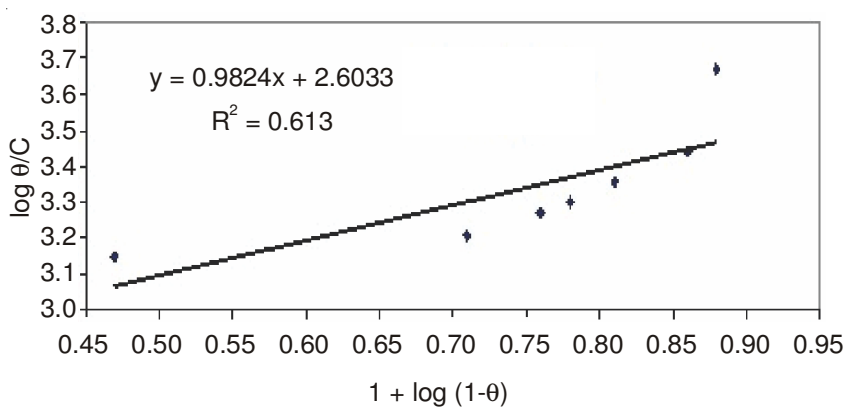

Fig. 10. Flory-Huggins adsorption isotherms at $25{ }^{\circ} \mathrm{C}$ for $p$-cresol (V)

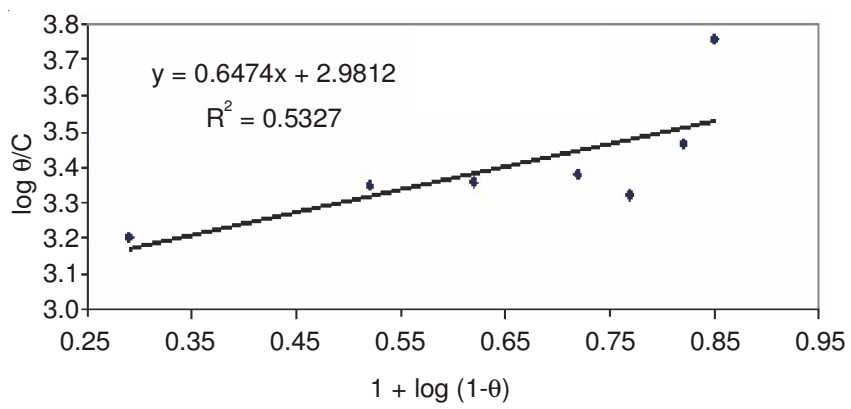

Fig. 11. Flory-Huggins adsorption isotherms at $25^{\circ} \mathrm{C}$ for $m$-cresol (VI)

to the formation of either electrostatic or covalent bonding between the adsorbents and the metal surface atoms ${ }^{27}$.

The kinetic adsorption isotherm may be written in the form $^{28}$ :

$$
\log \frac{\theta}{1-\theta}=\log \mathrm{k}^{\prime}+\mathrm{y} \log \mathrm{C}
$$

where $\mathrm{y}$ is the number of inhibitor molecules occupy one active site. The binding constant of adsorption $\mathrm{K}=\mathrm{k}^{1 / \mathrm{y},}$ where $1 / \mathrm{y}$ is the number of the surface active sites occupied by one molecule of the inhibitor and $\mathrm{k}$ is the binding constant. Figs. 12-17 linear relation of the inhibitor molecules between $\log \theta / 1-\theta$ and $\log \mathrm{C}$ at $25^{\circ} \mathrm{C}$ and the calculated values of $1 / \mathrm{y}$ and $\mathrm{K}$ given in Table-3.

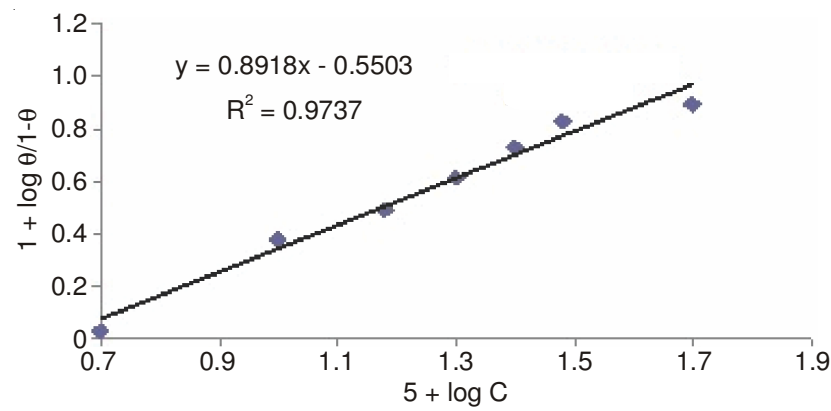

Fig. 12. Kinetic adsorption isotherms for phenol (I) at $25^{\circ} \mathrm{C}$

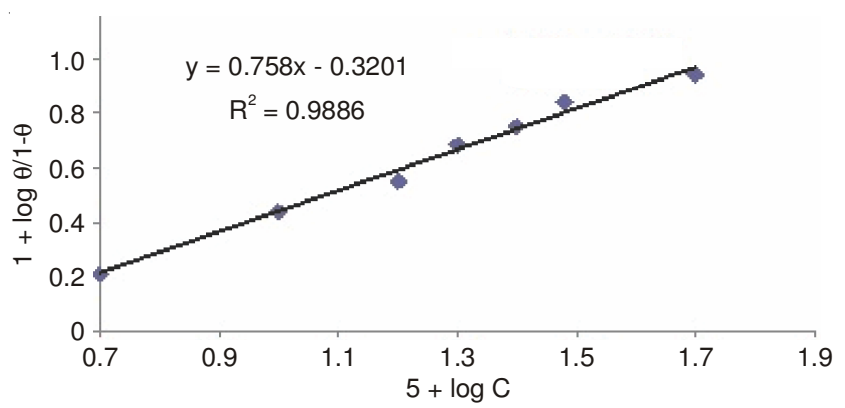

Fig. 13. Kinetic adsorption isotherms for $p$-amino phenol (II) at $25^{\circ} \mathrm{C}$

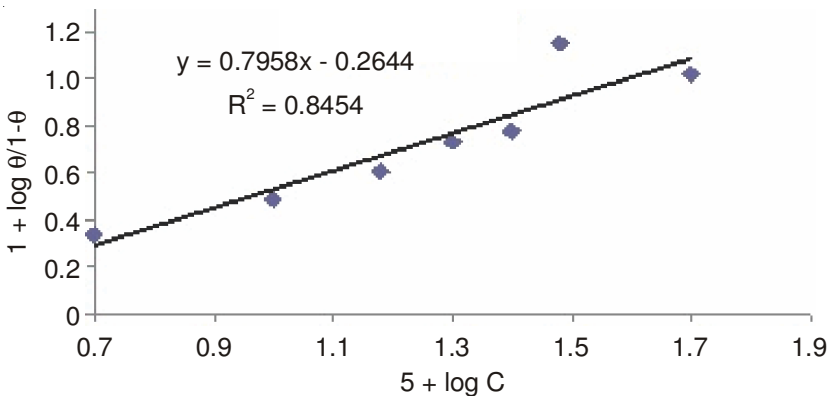

Fig. 14. Kinetic adsorption isotherms for $o$-amino phenol (III) at $25^{\circ} \mathrm{C}$

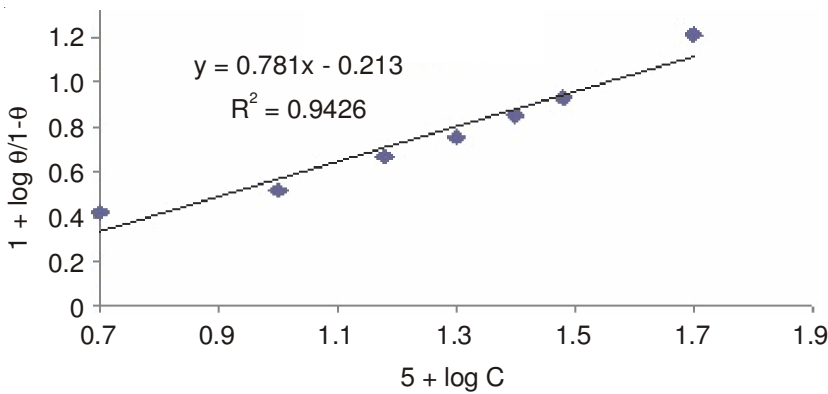

Fig. 15. Kinetic adsorption isotherms for $o$-cresol (IV) at $25^{\circ} \mathrm{C}$

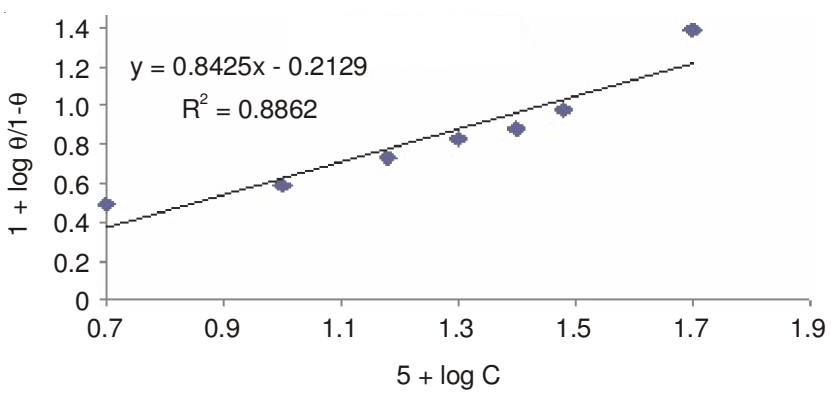

Fig. 16. Kinetic adsorption isotherms for $p$-cresol (V) at $25^{\circ} \mathrm{C}$

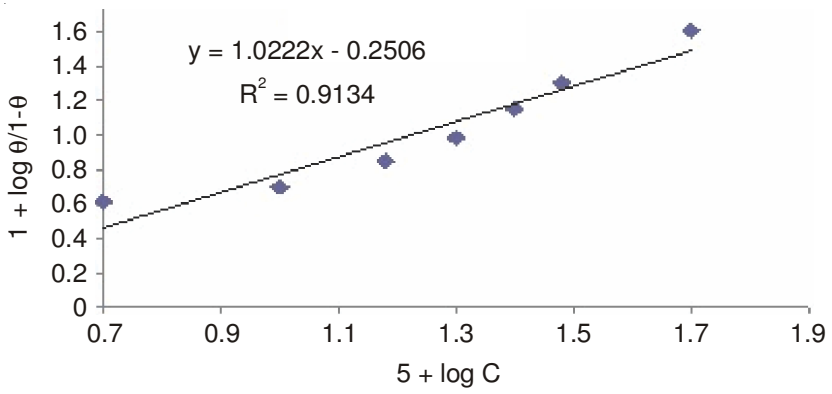

Fig. 17. Kinetic adsorption isotherms for $m$-cresol (VI) at $25^{\circ} \mathrm{C}$

The values of 1/y depend on the type of phenols derivative. From Table-4 it is obvious that, the value of $1 / y$ for $m$-cresol (VI) is approximately one. It is suggested that the compound attached to one active site per inhibitor molecule.

For other inhibitors [phenol (I), p-amino phenol (II), $o$-amino phenol (III), $o$-cresol (IV) and $p$-cresol (V)], the values of $1 / y$ higher than one, indicating that, the given inhibitors molecules are attached to more one active site.

The free energy of adsorption $\left(\Delta \mathrm{G}_{\mathrm{ads}}\right)$ at different concentration was calculating from the following equation:

$$
\Delta \mathrm{G}_{\mathrm{ads}}=-\mathrm{RT} \ln (55.5 \mathrm{~K})
$$

The value 55.5 is the concentration of water in the solution $\mathrm{mol} / \mathrm{L}$. 


\begin{tabular}{|c|c|c|c|c|c|}
\hline \multicolumn{6}{|c|}{$\begin{array}{l}\text { TABLE-4 } \\
\text { VALUES OF K, X AND 1/y OF PHOSPHORIC ACID IN PRESENCE OF DIFFERENT PHENOLS } \\
\text { DERIVATIVES TO LANGMUIR, FLORY-HUGGINS AND KINETIC ADSORPTION ISOTHERM }\end{array}$} \\
\hline \multirow{2}{*}{ Compounds } & \multicolumn{2}{|c|}{ Flory-Huggins } & \multicolumn{3}{|c|}{ Kinetic adsorption isotherm } \\
\hline & $\mathrm{X}$ & $\mathrm{K}$ & $\mathrm{Y}$ & $1 / \mathrm{y}$ & $\mathrm{K}$ \\
\hline Phenol (I) & 1.4396 & 1669.39 & 0.8918 & 1.12 & 810.59 \\
\hline p-Amino phenol (II) & 2.1706 & 1721.95 & 0.7572 & 1.32 & 294.04 \\
\hline$o$-Amino phenol (III) & 1.8727 & 2027.83 & 0.6903 & 1.45 & 188.93 \\
\hline$o$-Cresol(IV) & 1.4195 & 2913.83 & 0.7810 & 1.28 & 491.81 \\
\hline$p$-Cresol(V) & 2.3713 & 2980.67 & 0.8425 & 1.19 & 997.01 \\
\hline$m$-Cresol(VI) & 0.6374 & 2682.53 & 0.9858 & 1.01 & 5640.09 \\
\hline
\end{tabular}

The values of $\Delta \mathrm{G}_{\mathrm{ads}}$ are given in Table-5. In all cases, the $\Delta \mathrm{G}_{\text {ads }}$ values are negative and lie in the range of 26.56-31.31 $\mathrm{KJ} / \mathrm{mol}$. The most efficient inhibitor shows the most negative value. This suggests that, they strongly adsorbed on the metal surface. The negative values of $\Delta \mathrm{G}_{\text {ads }}$ indicate that, the spontaneous adsorption of the inhibitor. It's found that, the $\Delta \mathrm{G}_{\mathrm{ads}}$ values are more positive than $-40 \mathrm{~K} \mathrm{~J} / \mathrm{mol}$ indicating that the inhibitors are physically adsorbed on the metal surface. Similar results had also been reported ${ }^{29}$.

TABLE-5

VALUES OF FREE ENERGY OF ADSORPTION $\left(\mathrm{kJ} \mathrm{mol}^{-1}\right)$ OF PHOSPHORIC ACID IN PRESENCE OF DIFFERENT PHENOLS DERIVATIVES USING DIFFERENT METHODS

\begin{tabular}{lcc}
\hline \multirow{2}{*}{ Compounds } & \multicolumn{2}{c}{$-\Delta \mathrm{G}_{\text {ads }}\left(\mathrm{kJ} \mathrm{mol}^{-1}\right)$} \\
\cline { 2 - 3 } & Flory-Huggins & Kinetic adsorption isotherm \\
\hline Phenol (I) & 28.35 & 26.56 \\
$p$-Amino phenol (II) & 28.42 & 24.04 \\
$o$-Amino phenol (III) & 28.83 & 22.95 \\
$o$-Cresol (IV) & 29.73 & 25.32 \\
$p$-Cresol (V) & 29.78 & 27.07 \\
$m$-Cresol (VI) & 29.52 & 31.36 \\
\hline
\end{tabular}

Effect of temperature: The effect of temperature on the copper electropolishing rate in absence and presence of phenols derivatives was determined in the temperature range 25,30 , $35,40{ }^{\circ} \mathrm{C}$ and illustrated in Table- 6 . It observed that the electropolishing rate increases with temperature for different concentrations of organic compounds.

Thermodynamic treatment of the results: From the integrated form of the Arrhenius equation:

$$
\ln \mathrm{I}=-\frac{\mathrm{E}_{\mathrm{a}}}{\mathrm{RT}}+\ln \mathrm{A}
$$

where $\mathrm{R}$ is the gas constant $\left(8.314 \mathrm{~kJ} \mathrm{~mol}^{-1}\right), \mathrm{E}_{\mathrm{a}}$ is the activation energy and $\mathrm{A}$ is the frequency factor. It can be seen that, the gradient is given by $-E_{a} / R$ and the intercept by $\ln A$ give the values of $\mathrm{E}$ for the compounds used.

The values for enthalpy of activation $\Delta \mathrm{H}^{*}$, entropy of activation $\Delta \mathrm{S}^{*}$ and free energy of activation $\Delta \mathrm{G}^{*}$ can be obtaining by using equations:

$$
\begin{gathered}
\Delta \mathrm{H}^{*}=\mathrm{E}_{\mathrm{a}}-\mathrm{RT} \\
\frac{\Delta \mathrm{S}^{*}}{\mathrm{R}}=\ln \mathrm{A}-\ln \left(\frac{\mathrm{kTe}}{\mathrm{h}}\right)
\end{gathered}
$$

\begin{tabular}{|c|c|c|c|c|}
\hline \multicolumn{5}{|c|}{$\begin{array}{c}\text { TABLE-6 } \\
\text { TTHERMODYNAMIC PARAMETERS FOR ELECTRODEPOSITION OF COPPER } \\
\text { IN PRESENCE OF PHENOL, } p \text {-AMINO AND } o \text {-AMINO AT } 25^{\circ} \mathrm{C} \\
\end{array}$} \\
\hline Conc. $\left(\mathrm{mol} \mathrm{L}^{-1}\right)$ & $\mathrm{E}_{\mathrm{a}}\left(\mathrm{kJ} \mathrm{mol}^{-1}\right)$ & $\Delta \mathrm{G}^{*}\left(\mathrm{~kJ} \mathrm{~mol}^{-1}\right)$ & $\Delta \mathrm{S}^{*}\left(\mathrm{~J} \mathrm{~mol}^{-1} \mathrm{k}^{-1}\right)$ & $\Delta \mathrm{H}^{*}\left(\mathrm{~kJ} \mathrm{~mol}^{-1}\right)$ \\
\hline \multicolumn{5}{|c|}{ Phenol (I) } \\
\hline $1.00 \mathrm{E}-05$ & 6.6642 & 57.26592 & -0.17811 & 4.16364 \\
\hline $5.00 \mathrm{E}-05$ & 8.6161 & 57.4188 & -0.17199 & 6.1373 \\
\hline $1.00 \mathrm{E}-04$ & 11.1814 & 57.629 .5 & -0.161977 & 9.33587 \\
\hline $5.00 \mathrm{E}-04$ & 12.5433 & 57.727 .07 & -0.159861 & 10.0645 \\
\hline $1.00 \mathrm{E}-03$ & 13.0243 & 57.786 .68 & -0.15844 & 10.5455 \\
\hline $5.00 \mathrm{E}-03$ & 11.5827 & 57.905 .4 & -0.16368 & 9.10395 \\
\hline $1.00 \mathrm{E}-02$ & 12.4715 & 57.854 .9 & -0.16053 & 9.99275 \\
\hline \multicolumn{5}{|c|}{$p$-Amino phenol (II) } \\
\hline $1.00 \mathrm{E}-05$ & 13.5059 & 57.7883 & -0.15683 & 11.02708 \\
\hline $5.00 \mathrm{E}-05$ & 11.7423 & 57.814 & -0.1628 & 9.26352 \\
\hline $1.00 \mathrm{E}-04$ & 13.4603 & 58.00544 & -0.1577 & 10.98148 \\
\hline $5.00 \mathrm{E}-04$ & 13.1846 & 58.11443 & -0.159 & 10.70582 \\
\hline $1.00 \mathrm{E}-03$ & 14.9851 & 58.242 & -0.1534 & 12.506 \\
\hline $5.00 \mathrm{E}-03$ & 16.0355 & 58.3668 & -0.1503 & 13.5567 \\
\hline $1.00 \mathrm{E}-02$ & 18.6014 & 58.5231 & -0.1422 & 16.1225 \\
\hline \multicolumn{5}{|c|}{$o$-Amino phenol (III) } \\
\hline $1.00 \mathrm{E}-05$ & 6.6862 & 57.624 & -0.17916 & 4.20738 \\
\hline $5.00 \mathrm{E}-05$ & 5.7894 & 57.720 & -0.18249 & 3.31056 \\
\hline $1.00 \mathrm{E}-04$ & 7.0650 & 57.852 & -0.1787 & 4.58618 \\
\hline $5.00 \mathrm{E}-04$ & 8.4720 & 58.0185 & -0.17449 & 5.99325 \\
\hline $1.00 \mathrm{E}-03$ & 8.8610 & 58.13796 & -0.1736 & 6.3822 \\
\hline $5.00 \mathrm{E}-03$ & 9.2864 & 58.2634 & -0.1726 & 6.80756 \\
\hline $1.00 \mathrm{E}-02$ & 10.7887 & 58.4066 & -0.16802 & 8.30989 \\
\hline
\end{tabular}




\begin{tabular}{|c|c|c|c|c|}
\hline \multicolumn{5}{|c|}{$\begin{array}{c}\text { TABLE-7 } \\
\text { THERMODYNAMIC PARAMETERS FOR ELECTRODEPOSITION OF COPPER } \\
\text { IN PRESENCE OF } o \text {-CRESOL, } p \text {-CRESOL AND } m \text {-CRESOL AT } 25^{\circ} \mathrm{C}\end{array}$} \\
\hline Conc. $\left(\mathrm{mol} \mathrm{L}^{-1}\right)$ & $\mathrm{E}_{\mathrm{a}}\left(\mathrm{kJ} \mathrm{mol}^{-1}\right)$ & $\Delta \mathrm{G}^{*}\left(\mathrm{~kJ} \mathrm{~mol}^{-1}\right)$ & $\Delta \mathrm{S}^{*}\left(\mathrm{~J} \mathrm{~mol}^{-1} \mathrm{k}^{-1}\right)$ & $\Delta \mathrm{H}^{*}\left(\mathrm{~kJ} \mathrm{~mol}^{-1}\right)$ \\
\hline \multicolumn{5}{|c|}{$o$-Cresol (IV) } \\
\hline $1.00 \mathrm{E}-05$ & 6.4438 & 57.5265 & -0.17964 & 3.9649 \\
\hline $5.00 \mathrm{E}-05$ & 6.6862 & 57.62402 & -0.17916 & 4.2073 \\
\hline $1.00 \mathrm{E}-04$ & 5.9713 & 57.68906 & -0.18177 & 3.4925 \\
\hline $5.00 \mathrm{E}-04$ & 5.9027 & 57.773 & -0.18228 & 3.42397 \\
\hline $1.00 \mathrm{E}-03$ & 6.4855 & 57.8762 & -0.18067 & 4.0067 \\
\hline $5.00 \mathrm{E}-03$ & 6.7679 & 57.9888 & -0.1801 & 4.28919 \\
\hline $1.00 \mathrm{E}-02$ & 6.5044 & 58.0854 & -0.18131 & 4.0256 \\
\hline \multicolumn{5}{|c|}{$p$-Cresol (V) } \\
\hline $1.00 \mathrm{E}-05$ & 5.3584 & 57.379 & -0.1828 & 2.8796 \\
\hline $5.00 \mathrm{E}-05$ & 5.6506 & 57.5179 & -0.1823 & 3.17187 \\
\hline $1.00 \mathrm{E}-04$ & 5.7607 & 57.56616 & -0.18207 & 3.28192 \\
\hline $5.00 \mathrm{E}-04$ & 5.8439 & 57.64404 & -0.18205 & 3.36514 \\
\hline $1.00 \mathrm{E}-03$ & 5.3717 & 57.69218 & -0.1838 & 28.9299 \\
\hline $5.00 \mathrm{E}-03$ & 5.0401 & 57.73919 & -0.18506 & 2.56135 \\
\hline $1.00 \mathrm{E}-02$ & 5.4567 & 57.81215 & -0.18391 & 29.77789 \\
\hline \multicolumn{5}{|c|}{$m$-Cresol (VI) } \\
\hline $1.00 \mathrm{E}-05$ & 7.0218 & 57.2553 & -0.1767 & 4.5430 \\
\hline $5.00 \mathrm{E}-05$ & 6.2807 & 57.3180 & -0.1794 & 3.8019 \\
\hline $1.00 \mathrm{E}-04$ & 6.3887 & 57.3624 & -0.1792 & 3.9098 \\
\hline $5.00 \mathrm{E}-04$ & 7.3771 & 57.4404 & -0.1762 & 4.8982 \\
\hline $1.00 \mathrm{E}-03$ & 7.7779 & 57.5266 & -0.1751 & 5.2991 \\
\hline $5.00 \mathrm{E}-03$ & 6.8480 & 57.5705 & -0.1784 & 4.3692 \\
\hline $1.00 \mathrm{E}-02$ & 5.8689 & 57.6152 & -0.1818 & 3.3901 \\
\hline
\end{tabular}

$$
\Delta \mathrm{G}^{*}=\Delta \mathrm{H}^{*}-\mathrm{T} \Delta \mathrm{S}^{*}
$$

where $\mathrm{k}$ is Boltzmann's constant, e $=2.7183$, h is Plank's constant, $\mathrm{A}$ is Arrhenius constant, $\mathrm{T}$ is absolute temperature and $\mathrm{R}$ is the universal gas constant. The adsorption is usually followed by liberation of heat of adsorption, so that $\mathrm{E}_{\mathrm{a}}<0$, consequently the rate of adsorption decreases with temperature and as a result, the surface coverage at given concentration decreases with increasing temperature. It is well known that an increase in the heat of adsorption leads to an increase in the energy of adsorption forces. However rising of the temperature acts in the reverse direction, increasing the kinetic energy of the molecules, facilitating disruption (consequently in the physical adsorption). In absence of organic substance, the results fit a straight line with an activation energy equals to $31.935 \mathrm{~kJ} \mathrm{~mol}^{-1}$ which is higher than the values obtained when organic substance was used as inhibitor.

Thus, the high values of activation energy show that (a) The rate of electropolishing of copper from phosphoric acid decreased by adding small amounts of the organic substances at temperature above $25^{\circ} \mathrm{C}$. (b) The adsorption process is physical adsorption and molecules of organic substance disrupted at temperature above $30{ }^{\circ} \mathrm{C}$ completely.

Tables 6 and 7 show that, the entropy $\Delta \mathrm{S}^{*}$ possess height negative values indicating a highly ordered organic species in the solution under investigation. These values found to be independent on the type of amide and dipolar aprotic solvents.

\section{REFERENCES}

1. P.T. Gilber and L.L. Shreir, Copper and Copper Alloy in Corrosion, Newnes-Butterworths, London, UK, edn. 2, p. 436 (1976).

2. R. Schumacher, A. Muller and W. Stockel, J. Electroanal. Chem., 219 , 311 (1987).

3. A.H. Moreira, A.V. Beriedefti, P.L. Calo and P.T.A. Sumodjo, Electrochim. Acta, 38, 981 (1993)
4. L.F.A. Da Costa and S.M.L. Agostinho, Corrosion, 35, 472 (1989).

5. G. Moretti, V.V. Molokanov, G. Quartarone and A. Zingales, Corrosion, 54, 135 (1998).

6. K.F. Khaled and N.I. Hackerman, Electrochim. Acta, 49, 485 (2004).

7. D.Q. Zhang, L.X. Gao and G.D. Zhou, Corros. Sci., 46, 3031 (2004).

8. A.G. Christy, A. Lowe, V. Otieno-Alego, M. Stoll and R.D. Webster, J. Appl. Electrochem., 34, 225 (2004).

9. C. Wang, S. Chen and S. Zhao, J. Electrochem. Soc., 151, 11 (2004).

10. H. Otmacic and E. Sttupnisek-Lisac, Elactrochim. Acta, 48, 985 (2002).

11. M.A. Elmorsi and A.M. Hassanein, Corros. Sci., 41, 2337 (1999).

12. M. Scendo, D. Poddebniak and J. Malyszko, J. Appl. Electrochem., 33, 287 (2003).

13. H. Otmacic, L. Telegdi, K. Papp and E. Stupnisek-Lisac, J. Appl. Electrochem., 34, 545 (2004).

14. M.G. Fontana and K.W. Staehle, Advances in Corrosion Science and Technology, Vol. 1, Plenum Press, New York (1970).

15. P.A. Jaquet, Trans. Electrochem. Soc., 69, 629 (1936).

16. N. Hackerman and R. Hard, First International Congress of Metallic Corrosion, Butterworth, London, p. 166 (1962).

17. H.F. Walton, J. Electrochem. Soc., 97, 219 (1950).

18. C.R. Wilke, M. Eiesenberg and C.W. Tobias, J. Electrochem. Soc., 100, 513 (1953).

19. G.M. El-Subruiti, A.M. Ahmed and M.G. Koretam, Bull. Electrochem., 19, 185 (2003).

20. S.T. Mayer, R.J. Contolini and A.F. Bernhardt, J. Electrochem. Soc., 141, 2503 (1994).

21. N.M. El-Mallah, A.M. Ahmed and L.F. Gado, J. Dispersion Sci. Technol., 31, 1579 (2010).

22. F. Mansfeld and J.V. Kenkel, Corros. Sci., 15, 767 (1975).

23. D. Landolt, Electrochim. Acta, 32, 1 (1987).

24. A.A. Taha, S.H. Sallam and A.M. Ahmed, Anti-Corros. Methods Mater., 41, 10 (1994).

25. A. Einstein, Proc. Royal Soc., Math. Phys. Eng. Sci., 106, 724 (1924).

26. S. Varvara, L. Muresan, A. Nicoara, G. Maurin and I.C. Popescu, Mater. Chem. Phys., 72, 332 (2001).

27. M.A. Quraishi and R. Sardar, Bull. Electrochem., 18, 515 (2002).

28. A.M. Abdel-Gaber, B.A. Abd El-Nabey, I.M. Sidahmed, A.M. ElZayady and M. Saadawy, Corros. Sci., 48, 2765 (2004).

29. N. Hackerman and A.C. Mackrides, Eng. Chem., 46, 323 (1954). 